Kairi Kasearu, Dagmar Kutsar, Avo Trumm

University of Tartu, Estonia

\author{
INVOLUNTARY OUTSIDERS OR THOSE \\ JUST TAKING TIME OFF? \\ YOUNG PEOPLE WHO ARE NOT IN EDUCATION, \\ EMPLOYMENT OR TRAINING IN ESTONIA
}

\title{
INTRODUCTION
}

Young people are exposed to the highest risks of unemployment and inactivity and for this reason they are considered as a major target group of social inclusion policies in Europe (Warzywoda-Kruszyńska et al 2010). As Barry (2005) highlights, many young people today lack status, rights and power in society. They are constrained by poverty, their prolonged dependence on the family and the state of transition towards adulthood, and the limited opportunities of access to higher education, employment, housing, or citizenship make them vulnerable to social exclusion. Moreover the process of restructuration of family, employment, education and welfare institutions, responsible for youth transitions, have made the transition process to independent living even more risky and insecure than ever before (MacDonald 1997). Reduction of social vulnerability of young people and increasing their competitiveness and community involvement are effective tools to improve the cohesiveness and sustainability of the whole society.

The current paper focuses on NEET youth (not in education, employment or training) in Estonia. Our main question is why they are out of the regular track of transition to independent living. The quantitative data come from the Estonian Labour Force Survey (2011) and the qualitative material is based on 15 semistructured interviews with NEETs aged 16-27. Interviews were carried out in late 2012 in the frames of a research programme "Development of youth work quality". The programme was financed by the European Social Foundation.

\section{THE CONCEPT OF NEET}

The concept of NEET was developed in Britain in 1980s called up with changes in benefit system which left most of those aged 16-18 years without access to unemployment benefits (Furlong 2006). These were young people who did 
not fit into any traditional status for youth - they were not studying; they were not attending any training, neither were they employed. In the beginning they were referred to as "zero-status youth", later interpreted as youth "who count for nothing and were going nowhere" (Eurofound 2012).

The group of NEET, if defined in a narrow age-frame (16-18), is relatively homogeneous including young people who share similar and relatively clear-cut problems related to transition from school to work. Later studies and policy documents have greatly expanded the age limits of NEET from 16-18 to 15-29 or even up to 34. Currently, the official statistics of Eurostat disaggregates three age groups: $15-19,20-24$ and 25-29. The rationale behind of the extension of the age limits of NEET concerns the fact that transition of young people into independent adulthood occurs in a later age and the life stage of youth lasts longer (Roberts 2005). As a result the target group of 15-34 years-old NEETs comprises an extremely varied and complex range of different biographies, experiences, orientations, advantages and disadvantages, making the task to find appropriate policy solutions nearly unrealistic (MacDonald 2011; Coles et al 2010; Furlong 2006).

\section{NEETS AND TRANSFORMING SOCIETIES}

The emerging phenomenon of young NEETs in recent decades has been linked to transformation processes of societies. Namely, the global processes of individualization and de-instutionalisation of a life-course and individualization of social risks (Ring 2005; Giddens 1988; Beck 1996), result in weakening of institutional ties, rules and norms that significantly have impacts on individual decision-making process. Contemporary institutional norms are more often replaced by flexible individually driven choices.

The most significant events in a young person's life during the transition from childhood into independent adult life are moving from education to employment, achievement of social maturity, leaving parental home, family formation, etc. Formerly the transition of young people from school to work was firmly structured and strictly controlled by social institutions and age-related regulations. Today the situation is different: many young people start part-time and temporary employment during the school time, school completion can traditionally be followed by permanent work or university studies, but also by flexible combination of different activities (studying, working full or part-time, different forms of non-activity, etc.), resulting in different temporal social statuses (temporally employed, studying, temporally unemployed, combining work and study, etc.). Moreover, the institutions that most affect the lives of young 
people (school, family, labour market, housing market, social welfare, etc.), are by themselves significantly changed and unable to fulfil their roles effectively (MacDonald,1997). In the context of flexibility and variability, young people may loose their life-orientation and experience difficulties in making the most reasonable decisions.

According to several authors (Unt 2011; Trumm 2011; Kovacheva 2001; Illner 1998), the effect of de-instutionalisation has been much stronger in Central and East-European new EU member states, where the collapse of the strictly regulated old system has considerably increased flexibility and vulnerability of youth transitions if compared to the old EU members. The economic recession starting from the late 2000s has further worsened the process of young people's transitions towards independent living.

\section{NEETS AND CHANGING GENERATION OF YOUNG PEOPLE}

Beside the structural factors, generational changes in the attitudes, values and behaviour patterns of young people play an important role in development of the NEET phenomenon. Young NEETs are forming a generation, who feel and often are excluded from any social activity; as a result, they withdraw and close down in their homes or rooms for months, where they remain absorbed in their personal interests such as the internet, or social networking, video games, etc. They are often de-motivated, reconciled young people who cannot see any future in their lives (The Moving... 2010).

When a young age means a transition from childhood to adulthood (Coles 1995), it should be considered that adulthood can be identified by two different models: 1) an individualized model - feeling mature and autonomous, and 2) a relational model - stressing responsibility and caring for others (Thomson and Holland 2002). When an individual autonomy today is achieved at more early age, taking social obligations and responsibilities is increasingly postponed. IT seems being a functional tool for achieving personal autonomy without taking social responsibilities, at the same time preparing a favourable ground for formation of the NEET status.

\section{CATEGORIES OF NEET-YOUTH}

The reasons and the consequences of being NEET are very different. NEET is a category that contains a variety of subgroups with various mixtures 
of experiences, characteristics and needs. Eurofound report (2012: 24) points out five different categories of being a NEET:

- the conventionally unemployed, further subdivided as long-term and shortterm unemployed (the biggest in size group);

- the unavailable - youth with family care responsibilities and young people who are sick or have disabilities;

- the disengaged - youth who do not seek a job or education; they may be discouraged workers or those who are pursuing dangerous or asocial lifestyles;

- the opportunity seekers - youth who are actively seeking work or training, but are holding out from opportunities that they see as not benefitting their skills and status;

- the voluntary NEETs - youth who are engaged in other activities than work, such as travelling, art, music, and self-directed learning.

These categories include a mix of vulnerable and non-vulnerable young people, extremely disadvantaged and those who voluntarily stay outside of the labour market or education system. To conclude, obtaining of a NEET status is not only a result of unfavourable social conditions, lack of resources or restricted access but can be one's own short or longer-term rational choice as well.

The NEET-youth can be subdivided into core and floating NEETs. Core NEETs have been out of education and/ or labour market for a long time and they have more likely several intertwined social and behavioural problems. This group also comprises the 'generational NEETs' - young people who come from families where being unemployed is an accepted norm of doing adulthood (The Moving..., 2010; Airio et al 2004). The intergenerational transmission of NEET status from parents to children is rather a cultural than economic phenomenon. It means that the values, life-style and socio-cultural atmosphere in the parental home play greater role in youth transitions compared to the level of income and material assets (Kasearu et al, 2010, Ermich et al 2001).

The floating NEETs are young people who lack direction and motivation, they tend to move in and out of the NEET group, engage in low paid or temporary work or a short training course. (The Moving..., 2010).

\section{WHO ARE THE NEETS IN ESTONIA?}

The recent Eurofound (2012) study revealed that nearly 40,000 young people in Estonia aged 15-29 are NEET, which accounts for 15\% of all young people in the corresponding age group. Similar to other young people they form a very heterogeneous group of people with different statuses, experiences and attitudes. 
NEETs remain relatively invisible in the society. Being apart from school and work, they rarely participate in other public activities. They keep distance from politics, and perceive societal institutions and agencies as a threat to their autonomy and self-realization (The Moving..., 2010). Despite of the relative "invisibility", their exclusion from education and employment systems is a major social problem with significant negative consequences for both society and the economy - in 2011, the economic loss because of disengagement of young people from the labour market in Estonia was 238 million Euros that formed 1.5\% of GDP (Eurofound, 2012).

According to the Eurofound report (2012), the proportion of NEETs in the age group 15-29 was $14.9 \%$ in 2011 in Estonia. In the younger age group (15-24), the proportion of NEETs was somewhat lower (11.8\%) than among the older age group (20.2\%). The dynamic change of NEETs (figure 1) follows the changes in general economic situation of the country, being the lowest during the period of economic growth and making steep rise during the economic recession.

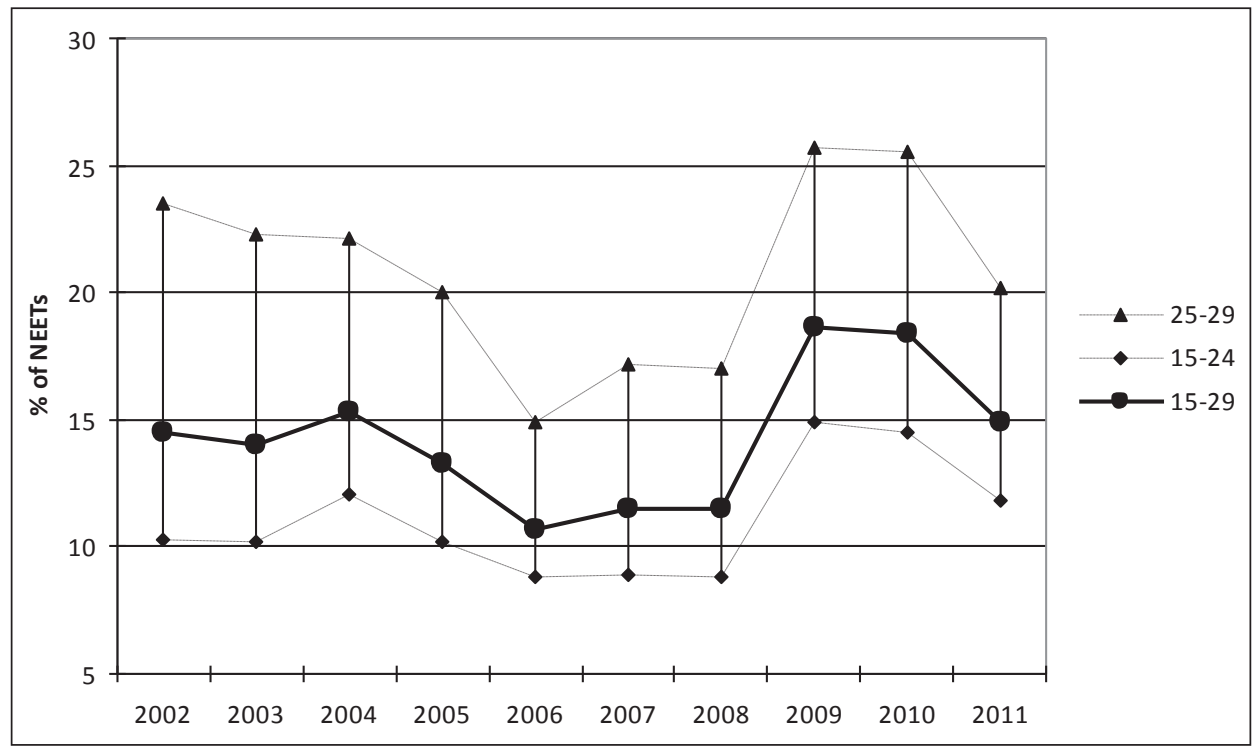

Figure 1. NEETs by age-groups in Estonia, 2002-2011 (\%)

Source: Eurostat.

In the Estonian Labour Force Survey (ELFS) the NEETs are defined as young people in the age range 15-29 - they are not employed or in military service and not studying or participating in training. The definition also includes those 
who are on maternity or parental leave and take care of a child. This is misleading because majority of them cannot be described as regular NEETs because they had been employed before the birth of a child. According to Estonian parental leave scheme, the parent has a right to return to the previous job position, i.e. the work contract is not terminated. Therefore, we included only those mothers and fathers to our analysis of NEET youth, whose status before taking parental leave was unemployed. Following these criteria, the proportion of NEETs in the age group 15-29 was $13.4 \%$ in 2011 . Out of them two thirds were 15-24 and one third were 25-29 years old.

Figure 2 illustrates the structure of NEETs by gender, education and employment experience. The risk to belong to the NEET group is higher for young men compared to young women; especially this concerns the younger age group. Also education is important factor for differentiating the NEET. In the younger age group, the NEETs have rather primary or secondary education, while the older age group gathers more often those with higher education. By gender the female NEETs have higher average educational level in both age groups meaning that women stay longer in education than men, but have fewer opportunities to enter or stay on the labour market.

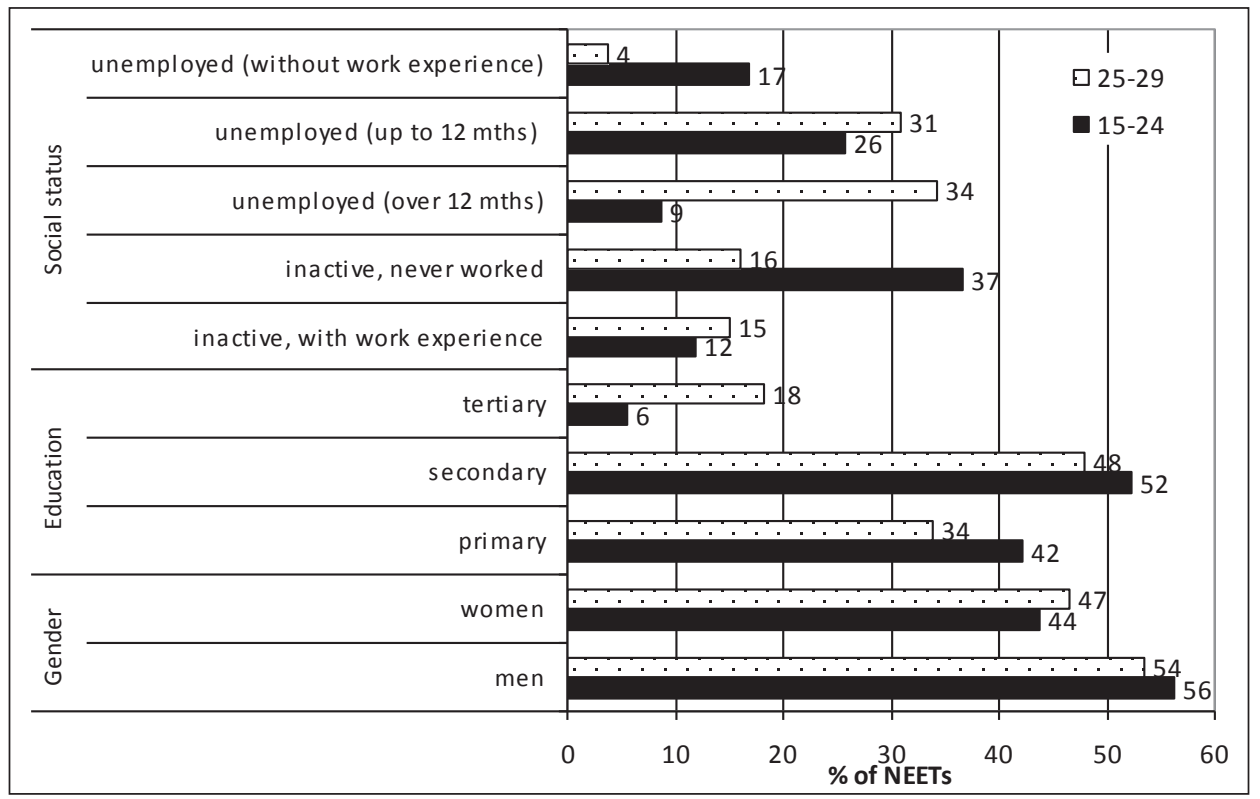

Figure 2. NEETs by gender, education and employment status (\%)

Source: ELFS 2011. 
Low educational level is a crucial factor determining a NEET status and its negative effect is magnifying over years. From young people with basic education in the age group 25-29, one third belongs to NEET. It suggests that the limited educational path has complicated their entrance to the labour market and / or holding a permanent job later; 65\% of NEETs in age group 25-29 are unemployed and more than half from them have been unemployed longer than a year. In the latter age group, the long-term unemployment is rather a problem for men $-42 \%$ of men and $25 \%$ of women have been unemployed over a year. In case of women, $39 \%$ have never worked or they describe their social status as "staying at home". In younger age group, those who have never worked form the largest group. It shows that for NEETs in the age 15-24, the main problem is the first entrance to the labour market. It is highly debated whether there are structural barriers against labour market entrance or young people's preferences and choices play crucial role. Our study shows that 'during last four weeks' $60 \%$ of NEETs have searched a job and $18 \%$ admit that they have not, but would like to start working. Finally, one fifth of the NEET are those, who agree that they do not want to work.

The main reason of inactivity (not searching a job) is illness, injury or disability (29\%) however, $15 \%$ did not want to work or search a job, and finally $14 \%$ declare that they stay on parental leave without a job contract before taking it. This suggests that the reasons, why young adults are not looking for a job, are rather personal and can be explained by their own choice. However, approximately ten per cent of NEETs express disappointment - they do not believe in a success of finding a job.

\section{PERCEIVED RISKS OF BECOMING NEET-YOUTH}

In the next section let's follow the perspectives of young NEETs and make an attempt for in-depth understanding how developmental risks have led them to the NEET status. First, let's stop on risks that can lead to drop-out from education that in its own right would cause the difficulties by entering to the labour market. More specifically, dropping out of school means a young person being left without necessary qualification - knowledge, skills and competences that are required on the labour market.

"Wrong" friends and truancy from school. Drop-outs from basic education (in Estonia this is nine years of schooling) stress the importance of learning at school and admit that they would have focused and put more forces to studies while they were in school. They connected the drop-out with emerging 
learning difficulties determined by devoting little time to studies, absence from school, finding "wrong friends" and obvious behaviour difficulties. As one young person explained:

Things got worse and worse for me. I like lost power to say no to things that happened to me. I felt unwillingness to change anything in my life, or to choose a right company - just leave the old one and start everything from zero. (M, $16 \mathrm{yrs})$

Harsh study environment. Young people are sometimes very fragile and have difficulties in coping with critics that are addressed to them. In case a young person perceives that he or she is not in favour, his or her capacities, interests or individuality do not matter and someone has acted badly, all this produces aversion and protest and may end up with indignation from studies.

This was a teacher of math, I saw, she did not bother about her work. She was fed up and wearied..., and she had such an evil nature that we all were afraid of her. I don't know, perhaps I was overreacting but somehow I started to fight against the system. Ok, I got retaliation. (F, $25 \mathrm{yrs}$ )

Parental home. The interviews demonstrated that parental home and parents are important for the NEET-youth and the lived life with parents still rests in their feelings. Parental breakup and the changes in the closest life environment are events with far-reaching consequences for a young person. Not everyone can cope with this if left alone without finding understanding, help or support.

I visited a psychologist and this was really crazy for me... absolutely intolerable that I must start living together with some new and strange man. I was not able to cope in school, later my grandmother from the father's side died, this was total hurtle for me. This was really hard. Such a big school and so many people and my father couldn't be always around when I needed him. (F, 21 yrs)

Parenting skills. Life transitions of youth are impacted by parenting skills - how much they are knowledgeable as parents, how much they can or wish to guide and control the lives of their children. Looking back, a young person may admit that parents did not set boundaries between do's and do not's as strictly as he or she would have needed, and the parental eye was in some important moments missing.

We can speak to each other and seems everything is ok but she [mother] has never been such a disciplining parent, even if this would have been right thing sometimes. When problems occurred she like did not know how to react. (F, 25 yrs)

Birth of a child, often unplanned life event in a young girl's life diverts her from the traditional life trajectory and paves the way towards the NEET status. 
Truancy from school and spending time with casual friends and acquaintances is the new reality for her.

I left school... you know, this was in my teens, I did not bother about school and later I had arguments with teachers so often that some day I realised I couldn't go there any more. And then I left and went to another school - for adults [...] and graduated the ninth form being gravid and... (F, 25 yrs)

Staying at home for taking care of a child is a serious obstacle to return to school. After longer stay at home motivation to go to work has decreased and former life plans loose sense. Parents, the child's father or other relatives often guarantee continued existence.

A young person with inadequate education and vocational skills faces tremendous problems with entering to the labour market. First of all, he or she lacks necessary qualification; low educational level sends negative signals to the potential employers producing mistrust towards the young job seeker. Missing work experience is also against the employer's expectations.

No... I have never worked. And ... the problem is that somehow I cannot have a job, because I have never practiced it. Employers require just that you must have it ... ok, they better should trust and you know ... and no need to teach and... But ok, I do not have this required work practice. (F, 18 yrs)

For NEETs in their 20s and with obtained general education becoming a NEET is related with drop-out from higher education, inability to find a job according to qualification or loss of a previous job. Drop-out from higher education is often related with several reasons, such as disappointment in the choice of the subject field, disliking the teachings methods and study routines.

Academic training did not suit to me - some topics were boring and some things I knew before. [...] In spite of this I have collected over 200 credit points. I have four specialities: journalism, economics, philosophy and Estonian philology. I don't care whether I have got the diploma or not $\ldots$ in the moment $(\mathrm{M}, 25 \mathrm{yrs})$

After the graduation of studies some young people deal with hobbies or carry out some interesting projects, and receive some income from these actions. Permanent and official job is not a priority for them, either their strategic preference or a choice.

I do not see a reason why to go to work elsewhere. Not that I do not care about working but because simply things are nicely settled now, plus I can reserve some time for myself and do things that interest me and let's see what tomorrow will bring. Perhaps I may not need to rush elsewhere. (M, $27 \mathrm{yrs})$ 
For the latter group of young people the NEET status is more a question of preferences and personal choices. Instead of official search of a job they prefer earning money by using alternative channels of non-formal or unregistered work. They are really interested in what they are doing and this is really important for them; they have flexible time schedules and do works that do not imply working under somebody's subordination. These young people have relatively good coping capacities. They value personal freedom, self-regulation and dare to exclude job offers that are not attractive to them.

Finding a job that would match with the obtained qualification causes problems for young people after graduation from higher or vocational education. They have invested in their studies with time, money and personal energy, and now they are interested in finding a job that suite to their competencies. Young people are aware about their worthiness and this is why they keep high expectations concerning their future job and the salary, wait and see.

Another reason for entering the NEET group is the case when transition from education to the labour market takes longer time. Young people call it as taking time off or rationalise this by the wish to collect ideas, enjoy life, etc. Taking time off will terminate ordinary life routine framed with external controls and later on return to the structured life may cause more problems than expected.

\section{CONCLUSION}

Although the concept of NEET is quite well known in Western Europe, for Eastern-European societies like Estonia as a social phenomenon it is relatively recently acknowledged. Our analyses indicate that among young adults, the NEET status is quite common and apparently the risk to belong to the NEET group during the transition from school to work has increased. The reasons why young people obtain the NEET status vary between those who have dropped out from compulsory education and those who have completed further education or even own a degree. However, in Estonia, unemployment is a common feature of the NEETs. The unemployed split into two groups - with and without eagerness of finding a job and with low and high expectations to the offered job opportunity.

In conclusion, both the situation that a NEET young person is facing and his or her future perspectives are dependent on age of reaching the NEET status. If this happens in his or her later years, then there has been more time and opportunities to collect educational and social capital as resources supporting the entrance to the labour market. However, diverting from institutionally determined 
life paths can direct towards alternative educational and job opportunities and thus a young person (even if relatively well-performing) can stay excluded from social mechanisms and regulations.

Opportunities of NEET youth under the legal age with inadequate education and social skills are scarce. The problems with employment, economic and social coping are unavoidable without external interventions.

\section{REFERENCES}

Airio I., Moisio P., and Niemelä M. (2004), Integenerational transmission of poverty in Finland in the 1990s. Department of Social Policy Series C: 13/ 2004. Turku: University of Turku Press.

Beck U. (1996), Risk and the provident state, [in:] S. Lash, B. Szerszynski, B. Wynne, (eds.) Risk, Environment and Modernity: Towards New Ecology. London: Sage Publications.

Coles B. (1995), Youth and Social Policy: Youth Citizenship and Young Careers, London: UCL Press.

Coles B., Godfrey C., Keung A., Parrot S., Bradshaw J. (2010). Estimating the Life-time Cost of NEET. Report. University of York. http://www.york.ac.uk/depts/spsw/research/neet.

Ermich J., Francesconi M., Pevalin D. (2001), The Outcomes for Children in Poverty. Department of Work and Pensions Research Report No 192.

Eurofound (2012), NEETs - Young people not in employment, education or training: Characteristics, costs and policy responses in Europe. Publications Office of the European Union, Luxembourg.

Furlong A. (2006), Not a very NEET solution, "Work, Employment and Society", vol. 20, no. 3.

Giddens A. (1988), The Third Way: The Renewal of Social Democracy, Cambridge: Polity Press.

Illner M. (1998), Underestimation of complexity: One major risk in the post-communist transformation, [in:] N. Genov, (ed.) Central and Eastern Europe Continuing Transformation, ParisSofia: UNESCO-MOST.

Kasearu K., Kutsar D., Trumm A. (2010), Determinants of social exclusion among the young in Estonia, Germany and United Kingdom, [in:] J. Leaman, M. Wörsching, (eds.), Youth in Contemporary Europe, New York, London: Routledge.

Kovacheva S. (2001), Flexibilisation of youth transitions in Central and Eastern Europe, "Young", vol. 9.

MacDonald R. (2011), Youth transitions, unemployment and underemployment: Plus ça change, plus c'est la même chose? "Journal of Sociology", vol. 47.

MacDonald R. (1997), Youth, the „Underclass “ and Social Exclusion, London: Routledge.

Ring P.J. (2005), The fourth pillar and the UK: Flexibility, risk and the deinstutionalization of the life course. The Geneva Papers on Risk and Insurance 30.

Roberts K. (2005), Youth, leisure and social inclusion, [in:] M. Barry (ed.) Youth Policy and Social Inclusion: Critical Debates with Young People, London: Routledge.

The Moving Project (2010). NEETS - Understanding Young People who are not in Education, Employment or Training. LLP-Leonardo da Vinci Program, The Moving Project, Study. http:// www.movingproject. eu/pdf/Research_Report___Understanding_NEETS.pdf.

Thompson M., Holland J. (2002), Inventing Adulthood: Young People's Strategies for Transition, Swindon: ESRC. 
Trumm A. (2011), Poverty in the Context of Societal Transitions in Estonia. Dissertationes Sociologicae Universitatis Tartuensis 4. Tartu: Tartu University Press.

Unt M. (2011), Youth entry into the labour market and early career outcomes, [in:] E. Saar (ed.), Towards a Normal Stratification and Order: Actual and Perceived Social Stratification in Post-Socialist Estonia, Hamburg: Peter Lang.

Warzywoda-Kruszyńska W., Rek M., Rokicka E. (2010), Poverty and Unemployment of Young Europeans from an Intergenerational Perspective, [in:]J. Leaman, M. Wörsching, (eds.), Youth in Contemporary Europe, New York, London: Routledge.

Kairi Kasearu, Dagmar Kutsar, Avo Trumm

\section{NEETs - MLODZI LUDZIE POZA EDUKACJĄ, ZATRUDNIENIEM I SZKOLENIAMI W ESTONII}

(streszczenie)

Artykuł jest omówieniem sytuacji osób młodych, które nie uczestniczą w systemie edukacyjnym, niesą zatrudnieni i nie uczestniczą w szkoleniach w Estoni. Autorzy artykułu zadają pytania o przyczyny ich wypadnięcia z normalnego przebiegu tranzycji do niezależnej dorosłości. Wykorzystując dane Estonian Labour Force Survey (2011) oraz 15 wywiadów swobodnych z poszukiwaną listą dyspozycji przeprowadzonych w 2012 r., autorzy wskazują na wewnętrzne zróżnicowanie sytuacji tej grupy młodych: oprócz osób będących niedobrowolnymi outsiderami, wskazują grupę młodych, którzy wycofali się z własnego wyboru. Obie grupy są jednak wykluczone ze społecznych mechanizmów i regulacji, stąd wymagają społecznej i politycznej uwagi. 